\title{
Trends in Vegetation Response to Drought in Sudano-Sahelian Part of Northern Nigeria
}

\author{
Blessing Bolarinwa Fabeku' ${ }^{1}$ Emmanuel C. Okogbue ${ }^{2}$ \\ ${ }^{1}$ Meteorology Unit, Ondo State University of Science and Technology, Okitipupa, Nigeria \\ ${ }^{2}$ Department of Meteorology, Federal University of Technology, Akure, Nigeria \\ Email: blesong4u@yahoo.com, emokogbue@gmail.com
}

Received 22 July 2014; revised 16 August 2014; accepted 10 September 2014

Copyright (C) 2014 by authors and Scientific Research Publishing Inc.

This work is licensed under the Creative Commons Attribution International License (CC BY). http://creativecommons.org/licenses/by/4.0/

(c) (i) Open Access

\section{Abstract}

This study was carried out to evaluate the drought occurrence and its implication on vegetation cover over the Sudano-Sahelian zone of the Northern part of Nigeria. Monthly mean Rainfall data for the period 40 years (1971-2010) were obtained from Nigeria Meteorological Agency (NIMET) for each of the meteorological stations present and functioning in this region for climatic analysis. Standardized Precipitation Index (SPI) was used to analyze drought occurrence on a time scale of five (5) months that cover the period of raining season over the study area. Also Satellite data over the selected part of the study area for three different epochs, 1986, 2000 and 2005 were used for vegetation response analysis. The SPI values were interpolated using Inverse Distance Weighted (IDW) interpolation technique in ArcGIS 9.3 to generate Drought Spatial Pattern Map for each selected modeled years. The vegetation response indicators used are land cover maps and Greenness Index (GI) maps. Land cover categories were classified into five levels: Dense Vegetation, less dense Vegetation, Settlement/built up, Bare Surface and Water body. The results based on the ground truth (rainfall) data show that many years of drought episode were experienced over the study area. On the other hand, the prime indicators (Land cover and GI maps) used in this study also depicts the changes that took place over the study area in response to this climatic anomaly (drought) and it could be noted that there was dramatic reduction in the occurrence towards the end of the last two decade, 1990-1999, which simply indicated improvement in rainfall even in 2000 and the later years.

\section{Keywords}

Drought Occurrence, Vegetation Response, Standardize Precipitation Index (SPI), Normalized Precipitation Index (NDVI), Greenness Index (GI), Drought Spatial Map 


\section{Introduction}

Most studies have revealed that several drought episodes hit the northern part Nigeria and left the region in a pitiable socio-economic condition. The persistence of this recurrent abnormality in weather condition (Drought) in this part of the country has been attributed to the prevalence of a stagnated anti-cyclonic circulation of the sub-tropical atmosphere over areas that normally should experience the rising arm of the tropical Hadley Cell circulation by mid-summer [1]-[3]. The circulation patterns in the tropics are strongly affected by heat inputs from such sources as warm ocean surfaces through the latent heat released in deep cumulus convection [4], which could be attributed to the substantial production of latent heat and moisture from the adjacent ocean. The geographical environment of the tropics is endowed with some important features like high plateaus and equatorial rainforests which also contribute their own quarter of heat that influenced the tropical circulation [5]. These produced heats vary with latitude and longitude and also on both annual and, in oceans' case, non-annual scales. One consequence of these circulation patterns is that rainfall patterns in West Africa, where northern Nigeria is situated, show annual variation, and this fluctuation persists over a long period. Studies have revealed that variations in West African rainfall patterns are tele-connected with distant locations phenomenon like El-Nino [6] [7].

Rainfall measurement in Nigeria which can be dated back to over a century ago, and there had been reports indicating some period in the past to have experienced low rainfall and drought conditions, a typical example is that of Sahelian droughts of late 1960s that lingered on till 1985/87 affected northern Nigeria, which had tremendous socio-economic impacts on the areas with pressure on available resources reported to be on the increase in the face of a fluctuating rainfall regime [8].

Most of the drought events in the Sahel-Sudano region of northern Nigeria have been found to be associated with a delayed onset of the rainy season and early cessation of the rains, which results in drastic reduction of the length of the rainy season. For example, most studies within the Sahel region have shown a significant trend towards false onset, late or delayed onset of the summer rains over a period of three decades from 1969 to 1998 [9]-[11].

\section{Area of Study}

The study area covers twelve synoptic stations (as depicted in Figure 1 below) in the Sudan-Sahel savannah

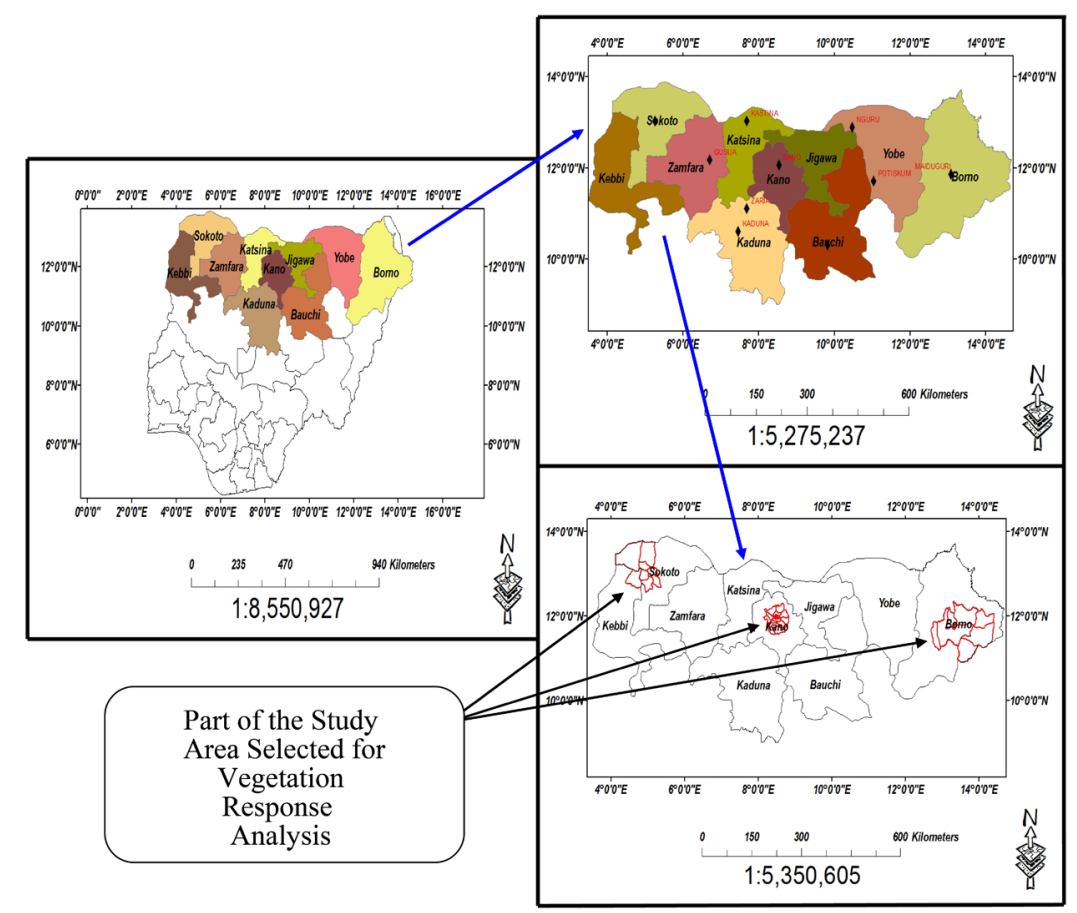

Figure 1. Map showing the study area. 
region located in northern Nigeria between latitude $10^{\circ} \mathrm{N}$ and $14^{\circ} \mathrm{N}$ and longitude $4^{\circ} \mathrm{E}$ and $14^{\circ} \mathrm{E}$, and lies immediately to the south of Sahara desert.

The climate of the zone is savannah type with alternating wet and dry seasons. The rainfall in this region is less than $1000 \mathrm{~mm}$ per annum in only about five months in the year, especially between May and October. Rainfall in this zone is highly variable and the onset of the rain is erratic. The rainfall intensity is very high between the months of July and August. There is intrazonal difference in the amount of rainfall received by the Sudan-Sahel savannah. The southern part receives more rain and is less variable compared to the northern section.

The gross features of rainfall patterns in this region, as in other parts of the country are usually in association with what is often called the Inter Tropical Discontinuity (ITD) [12]-[15].

The movement of the ITD northwards across the country between January and August, and its retreat from the southern fringe of the Sahara desert, after August, cause much of Nigeria to experience seasonal rainfall [16]. The ITD itself is the boundary over the continent between the dry Tropical Continental (cT) air of northern origin and the moist Tropical Maritime (mT) air of southern origin. Within the mT air mass is enclosed a number of rainfall producing systems, such as the disturbance lines (especially the easterly waves), squall lines and the two tropospheric jet streams. It is the magnitude of these systems that influences the amount and seasonal distribution of rainfall over the region [17].

\section{Materials and Methods}

\subsection{Data Acquisition and Source}

For this study, Landsat imagery for some selected parts of the study area as indicated in Figure 1 were acquired for three different epochs: 1986 (TM), 2000 (ETM+) and 2005(ETM+) from U.S. Geological Survey (Usgs) online (www.usgs.gov/). Also the meteorological data (monthly Rainfall amount in mm) was also obtained for climatic analysis over twelve synoptic stations across the study area for the period of 40 years (1970-2010) from Nigeria Meteorological Agency, Oshodi in Lagos (NIMET).

The study area and the boundary map carved out using the local government boundary map and Nigerian Administrative map on the scale of 1:15,140,906 were obtained from National Space Research and Development Agency, Abuja (NASRDA).

\subsection{Methods of Analysis}

\subsubsection{Drought Analysis}

For Drought analysis, Standardize Precipitation Index (SPI) for each station was determined using meteorological data (rainfall data) for period of 40 years on a time scale of five months which covers only the period of the raining season over the study area (Sudan-Sahel). SPI analysis was performed to evaluate and portray the event of meteorological drought over the study area using the equation below:

$$
S P I=\frac{X_{i k}-X_{i}}{\sigma_{i}}
$$

where $\sigma_{i}=$ standardized deviation for the ith station, $X_{i k}$ rainfall for the ith station and $k$ th observation, and $X_{i}$ mean rainfall for the ith station. SPI values of equal to or less than -0.50 was set as normal weather condition while all SPI values below normal were taken to indicate the occurrence of drought and SPI values above normal shows no drought (wet condition).

The SPI values gotten from the SPI analysis for all the stations were later interpolated using the Inverse Distance Weighted (IDW) interpolator in ArcGIS 9.3 environment. The interpolated maps are thus reclassified into different drought severity classes using the threshold SPI values adapted from Mckee et al. (1993) as shown in Table 1 and finally obtained Drought Spatial Pattern Map.

\subsubsection{Vegetation Response Analysis}

The satellite imagery downloaded has already been corrected from the manufacturer radio-metrically and geometrically to raster image (Geo-tiff). The images coordinate is in projection coordinate (WGS_84).

Maximum likelihood method of image classification was implored in Ilwis 3.5 environment to generate Land 
Table 1. Classes for Meteorological drought category (adapted from Mckee et al. 1997) [18].

\begin{tabular}{ccc}
\hline CATEGORIES & DESCRIPTION & SPI VALUES \\
\hline D0 & No Drought & -0.5 and above \\
D1 & Abnormally dry & $-0.5--0.7$ \\
D2 & Moderate Drought & $-0.8--1.2$ \\
D3 & Severe Drought & $-1.3--1.5$ \\
D4 & Extreme Drought & $-1.6--1.9$ \\
D5 & Exceptional Drought & -2 or less \\
\hline
\end{tabular}

Cover (LC) image comprising of vegetation cover types which is a prime indicator of drought condition since the survival of vegetation in the absence availability of water in the soil is impossible. LC image for respective epoch considered in this study was obtained.

Normalized Differential Vegetation Index (NDVI) calculation was performed to find out the changing pattern of the vegetation during the selected period of this study due to satellite data available (1986, 2000 and 2005). The following algorithm developed by Rouse et al. (1974) [19] was used for the NDVI computation.

$$
N D V I=\frac{(N I R-R)}{(N I R+R)}
$$

where: NIR and $R$ is the reflectance in the near-infrared (band4) and red (band3) portion of Electromagnetic spectrum respectively.

In order to generate Greenness Index (GI) map, the resulted NDVI maps were classified in ArcGIS 9.3 environment using the threshold NDVI values in Table 2.

\section{Results and Discussion}

\subsection{SPI Analysis}

The resulting SPI values for each of the meteorological stations from SPI analysis were plotted against each respective year considered in this study and presented in Figure 2.

Figure 3 and Figure 4 revealed the variation in the resulted SPI value at each station in Sahel Savanna and Sudan Savanna over the years of the study. It could be noted that drought started manifest over Sokoto and Maiduguri station in the year 1971 as their trends was found below -0.5 line on the graph. The drought event has already spread across all the stations in Sahel and almost those in the Sudano part of the study area in 1973.

This abnormal climatic phenomenon (drought) was recorded over Gusau, Kano, Yelwa station in 1976, Potiskum in 1977 and over Yelwa in Kebbi State 1978. The result revealed that the drought occurrence was more frequent in the 1970s and 1980s; starting from 1971-1973 the drought occurrence was more intensified and cut across the whole region in the study area. In 1976 and 1977, another peak was found below the -0.5 line over Gusua-Kano station and Potiskum station respectively. This experience repeats itself in 1983 but is not as much as that of 1973. 1980s was generally recorded as years of drought episode, but the drought occurrence seems to be retreating in 1991 except that of Kastina station which persist till 1999. The years starting from 2000 till 2010 was found to be drought free year all over the stations in the study area except Kano, Kaduna and Bauchi station.

\section{Drought Spatial Pattern Maps}

Some modeled years were selected and their respective SPI values over the meteorological stations within the study area were further processed using the threshold values to generate a Drought Severity Distribution Map of the study area as shown in Figures 5-7.

Figure 5(a) shows that 1973 was a dry year as drought severity varies across the study area and it could be noted that the case seems to be very serious in the Sahelian-States as the whole region experienced dry condition and most states considered in Sudano part of the study area was also left in drought condition except Kaduna. 
Table 2. Greenness index threshold values (Adapted from James G. Kongoti, 2005).

\begin{tabular}{cc}
\hline Land Cover Categories & NDVI Values \\
\hline Dense Vegetation & $+0.04-+1$ \\
Less Dense Vegetation & $+0.04-+0.07$ \\
Bare Surface Area & $-0.08-+0.04$ \\
Water Body & $-0.08--1$ \\
\hline
\end{tabular}

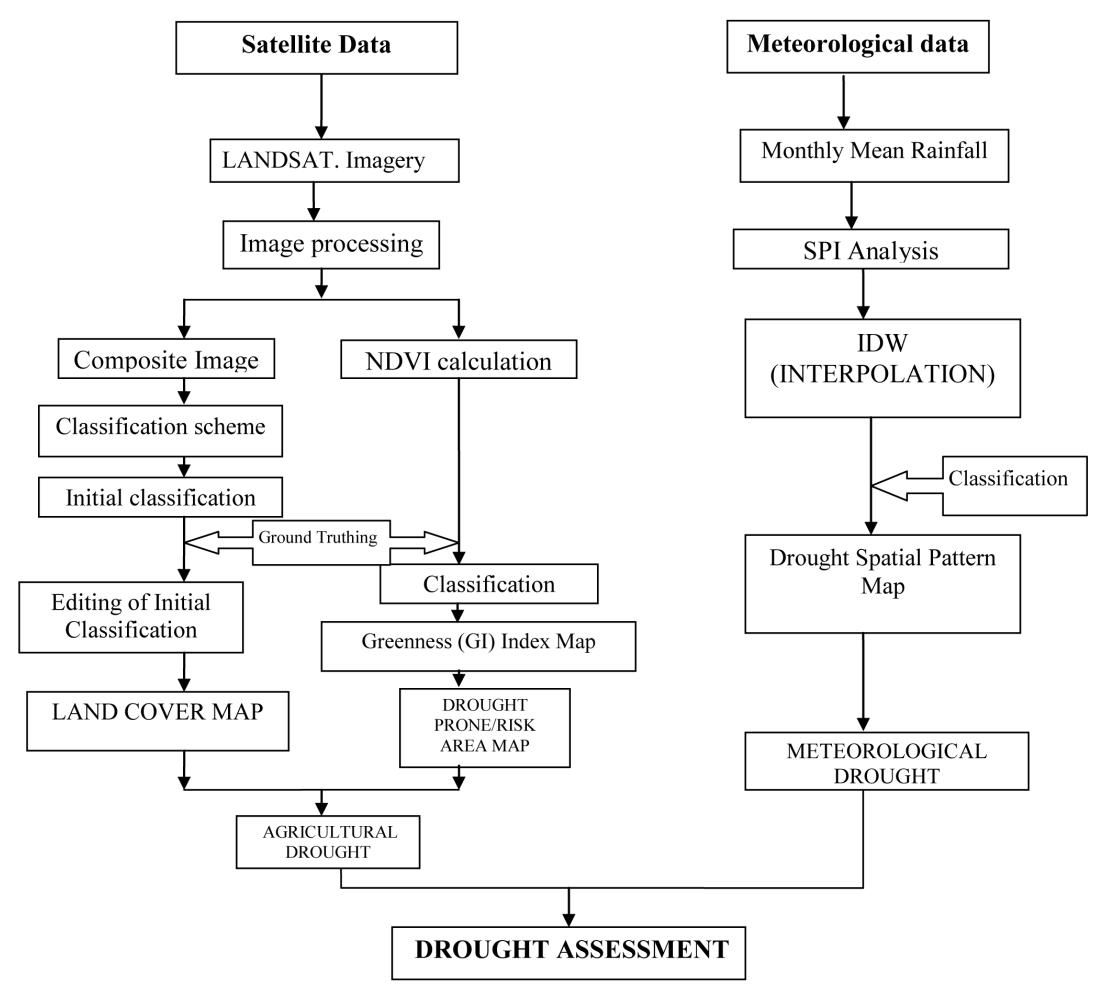

Figure 2. Flow chart of the methodology.

The most drought intensified category (Extreme drought) was recorded over Sokoto, Kano and Nguru station in Yobe state. Severe drought condition was also recorded over parts of Sokoto, Kano, jigawa, Yobe and Borno state. Major part of part of Borno state, Yobe, Kebbi, Kastina, Kano and some part of Jigawa and Sokoto state was under the influence of moderate drought condition, while abnormally dry condition cut across some part of Kebbi, Kastina and Kano state. Near normal was well pronounced over Kaduna.

Figure 5(b) shows the SPI spatial pattern over the study area for 1976, and the map revealed that near normal condition prevailed over the most part of the study area. Though, abnormal climate conditions ranged from abnormally dry to severe drought condition were still observed over some minority stations like yelwa, gusua and kano.

Figure 5(c) shows that, the improvements in climatic condition over the study area still persist.

Figure 5(d) shows the SPI spatial pattern over the study area for 1983, and the map revealed that 1983 was another year of drought episode as most serious drought condition (Exceptional drought) was experienced over Borno state and this was accompanied by Extreme, severe, and moderate drought condition cutting across the other part of the state. Extreme drought condition was recorded over Nguru station in Yobe state, some part of Jigawa state, Kastina and Kano state. Moderate drought condition also cut across Kastina, Kano, Jigawa and Yobe state. Abnormally dry condition was experienced over parts of Sokoto, Kebbi, Kastina and Yobe state. Finally, near normal condition was recorded over Sokoto, Kebbi, Zamfara, some minor part of Kastina and Kaduna.

Figure 6(a) shows the SPI spatial pattern map for 1987 over the study area, the legend depicts that the year 1987 was another year a drought occurrence was well pronounced over the study area. The most serious of all 


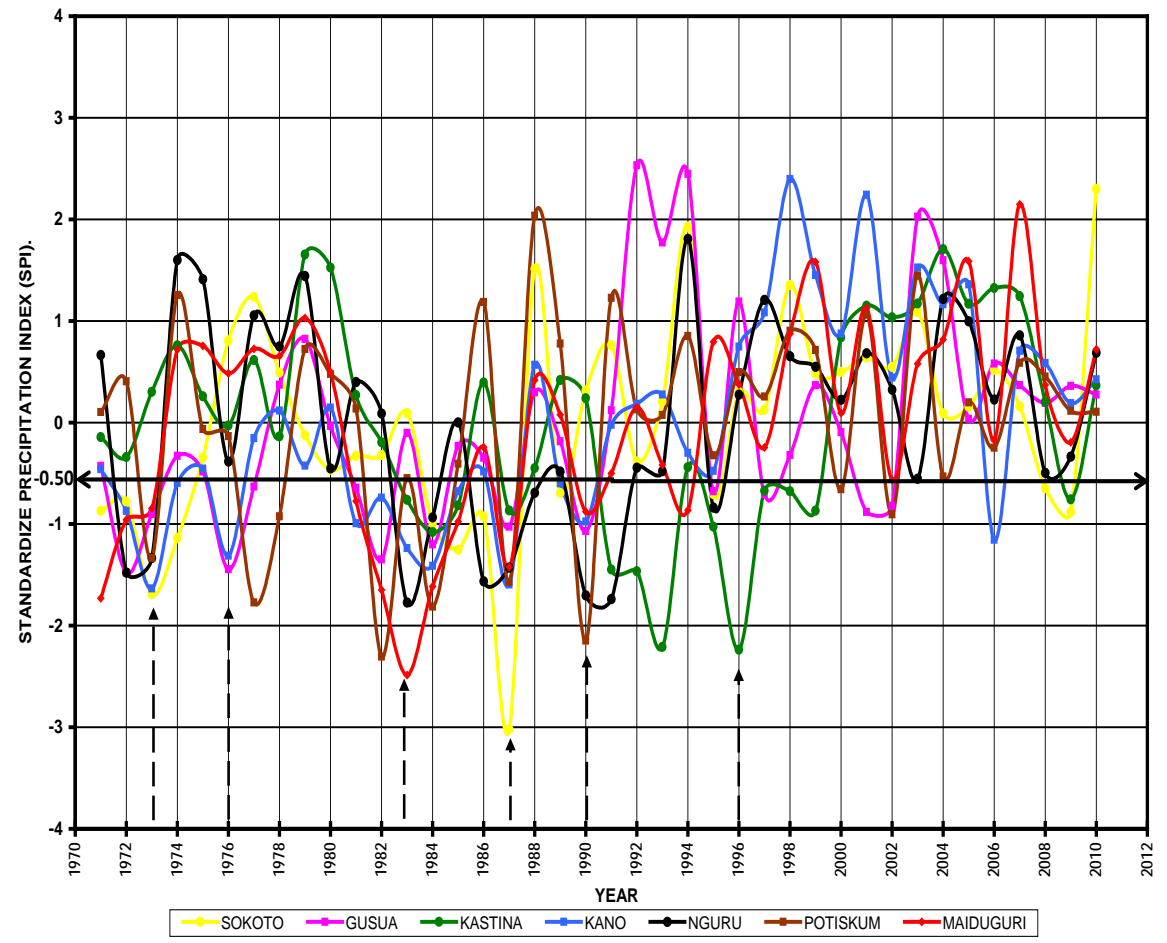

Figure 3. A graph of resulting Standardized Precipitation Index (SPI) values against each study year for period of 1971-2010 over each station in Sahelian Zone. The Black solid horizontal line indicates the line of -0.5 SPI value (Near Normal Condition).

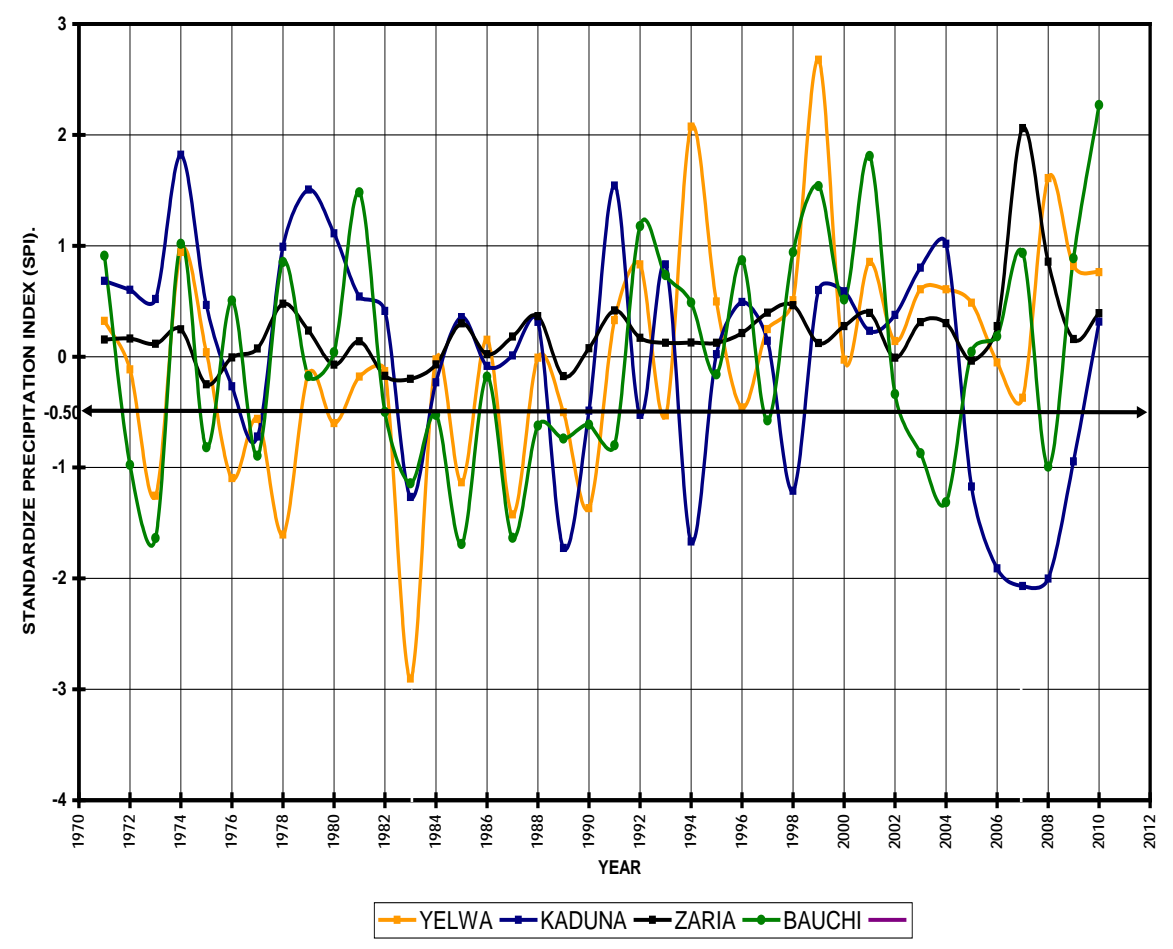

Figure 4. A graph of resulting Standardized Precipitation Index (SPI) values against each study year for period of 1971-2010 over each station in Sudan Savanna Zone. The Black solid horizontal line indicates the line of -0.5 SPI value (Normal). 


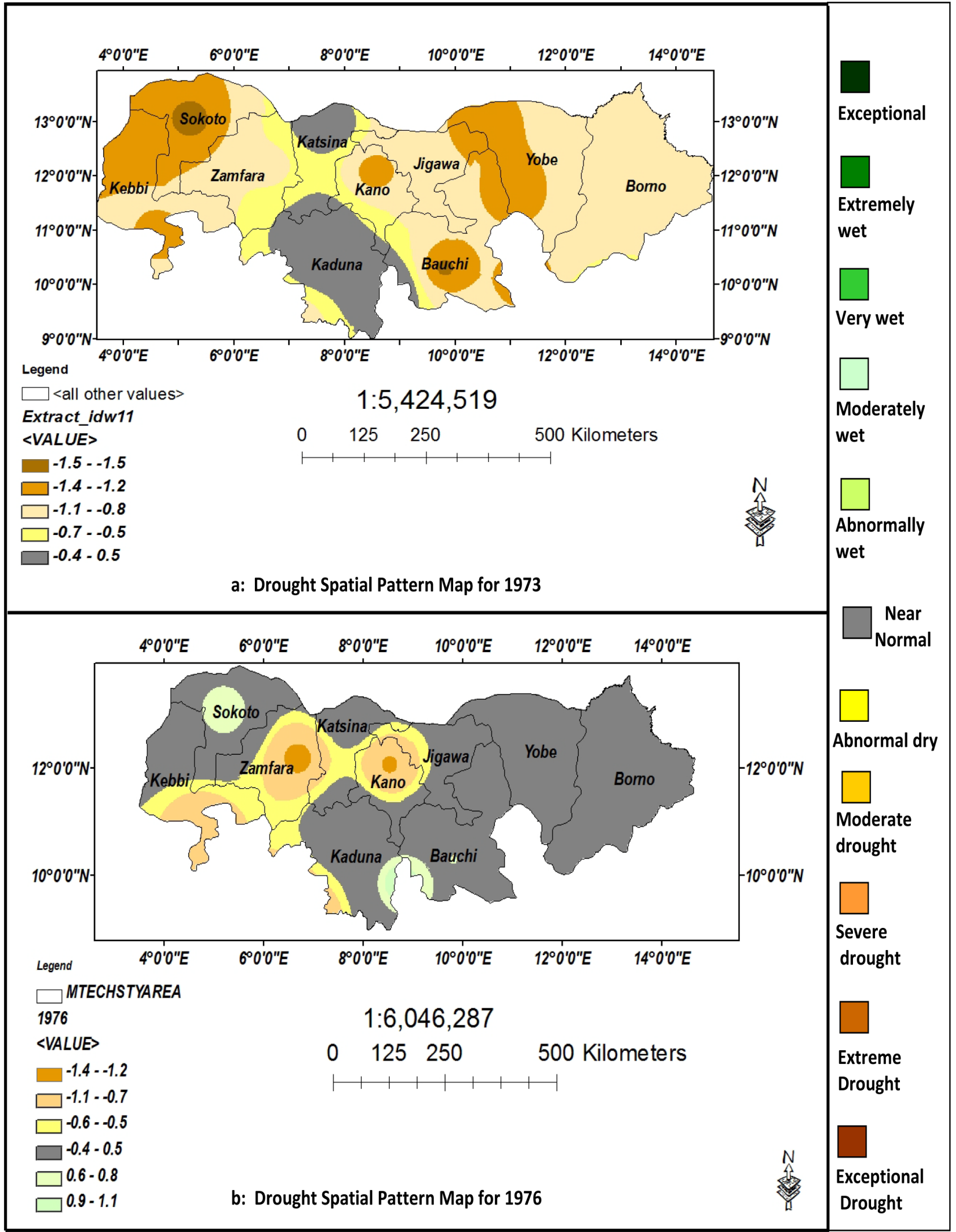




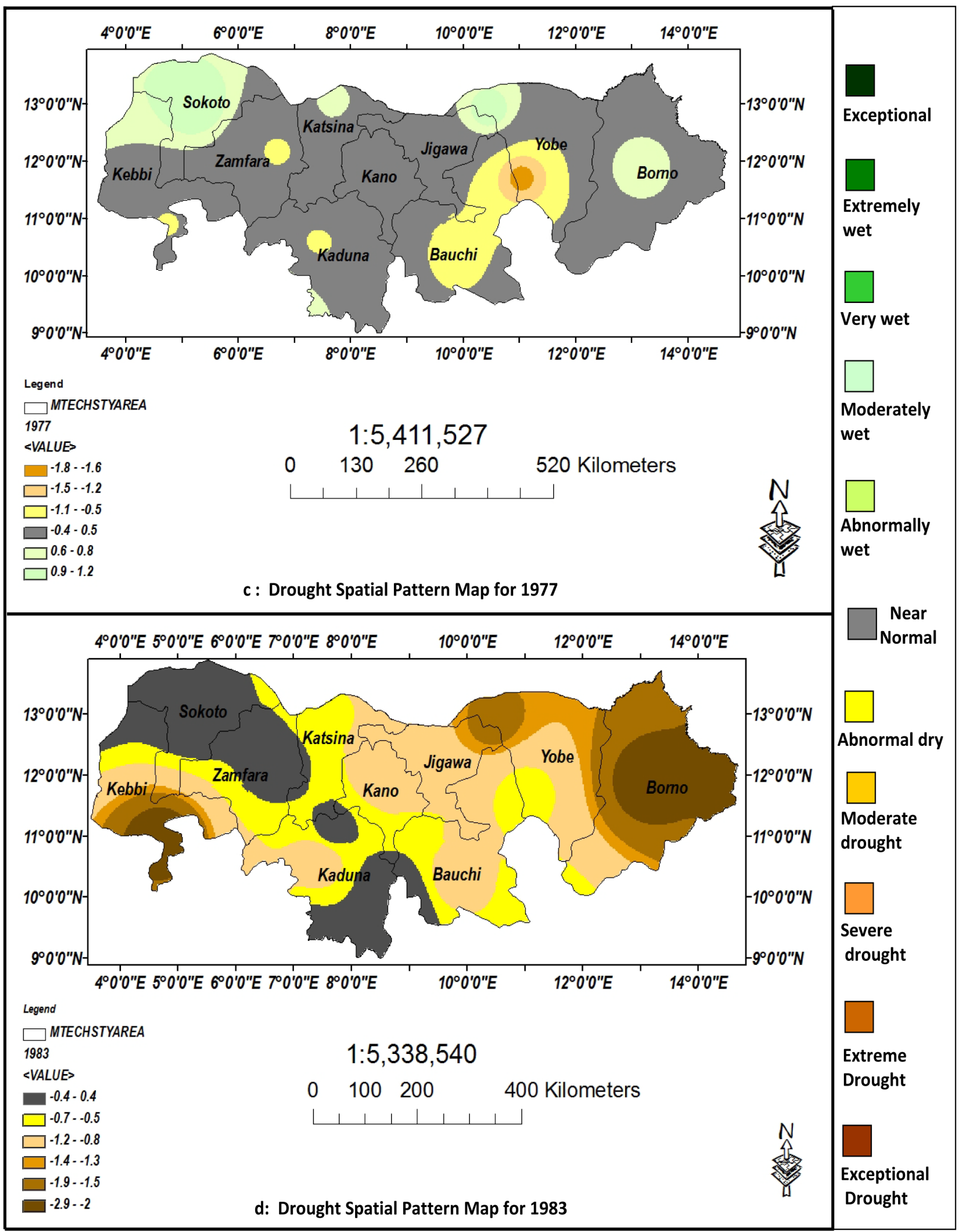

Figure 5. Drought spatial pattern maps for 1973, 1976, 1977 and 1983 over the study area. 


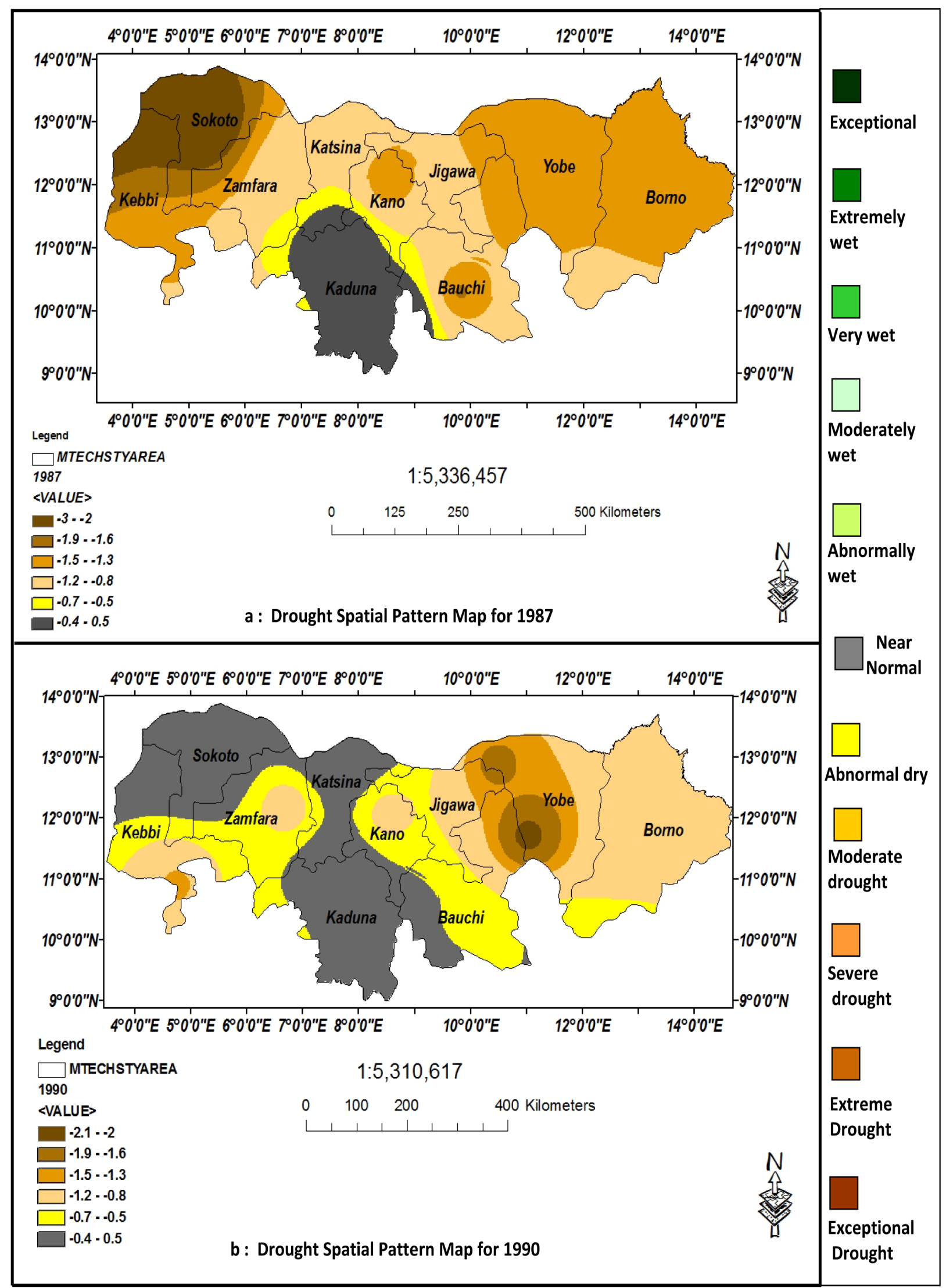




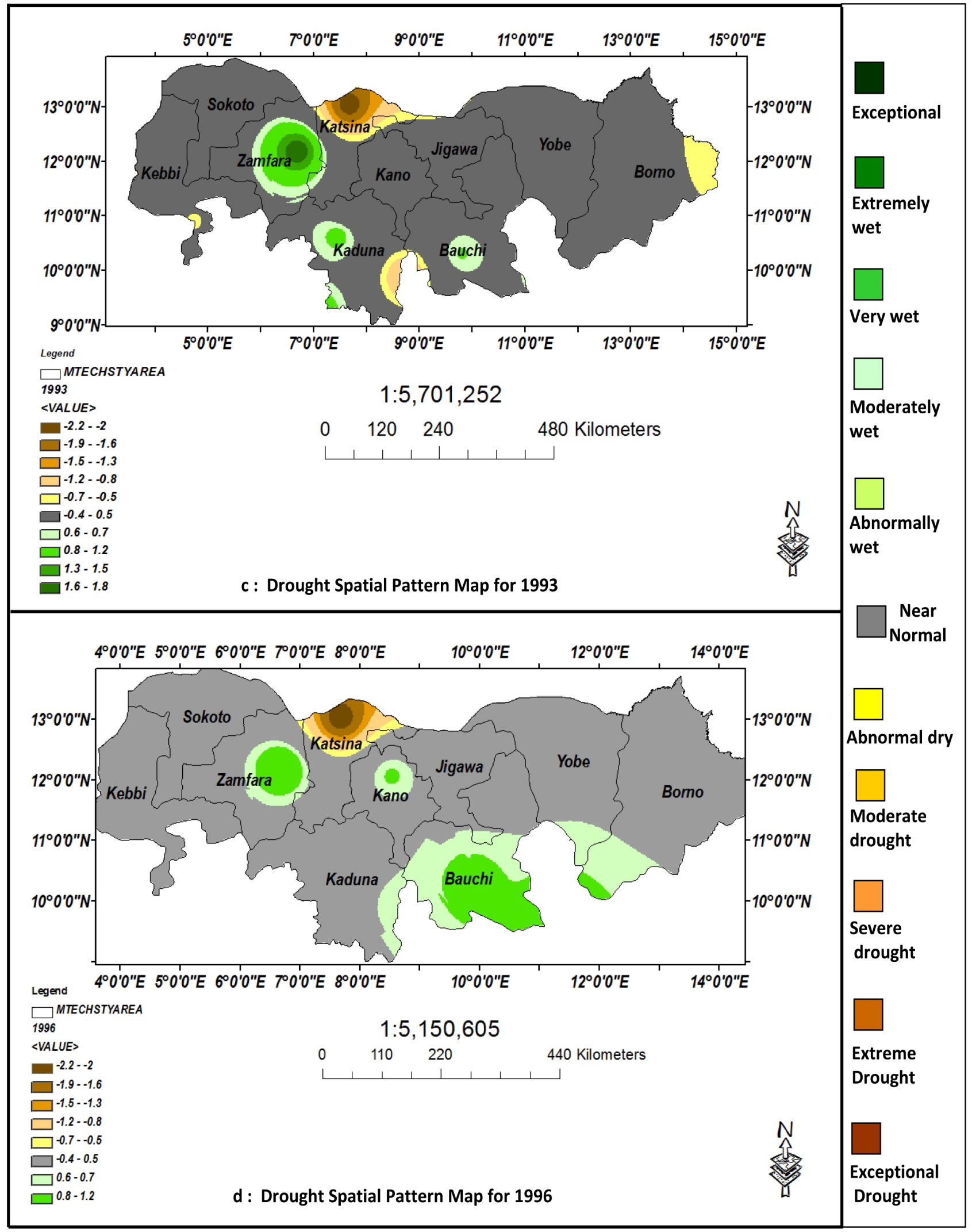

Figure 6. Drought spatial pattern map for 1987, 1990, 1993 and 1996 over the study area. 


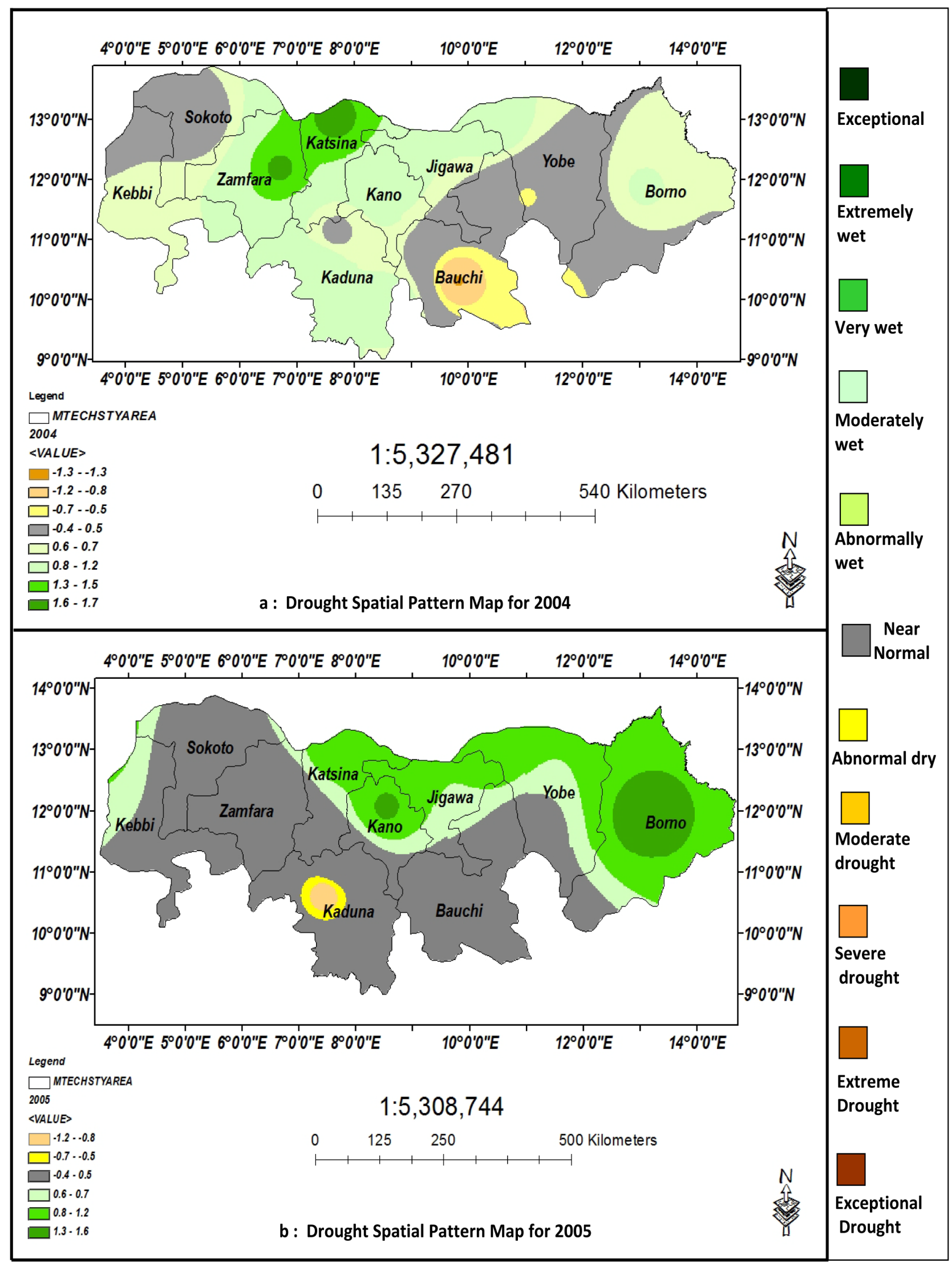




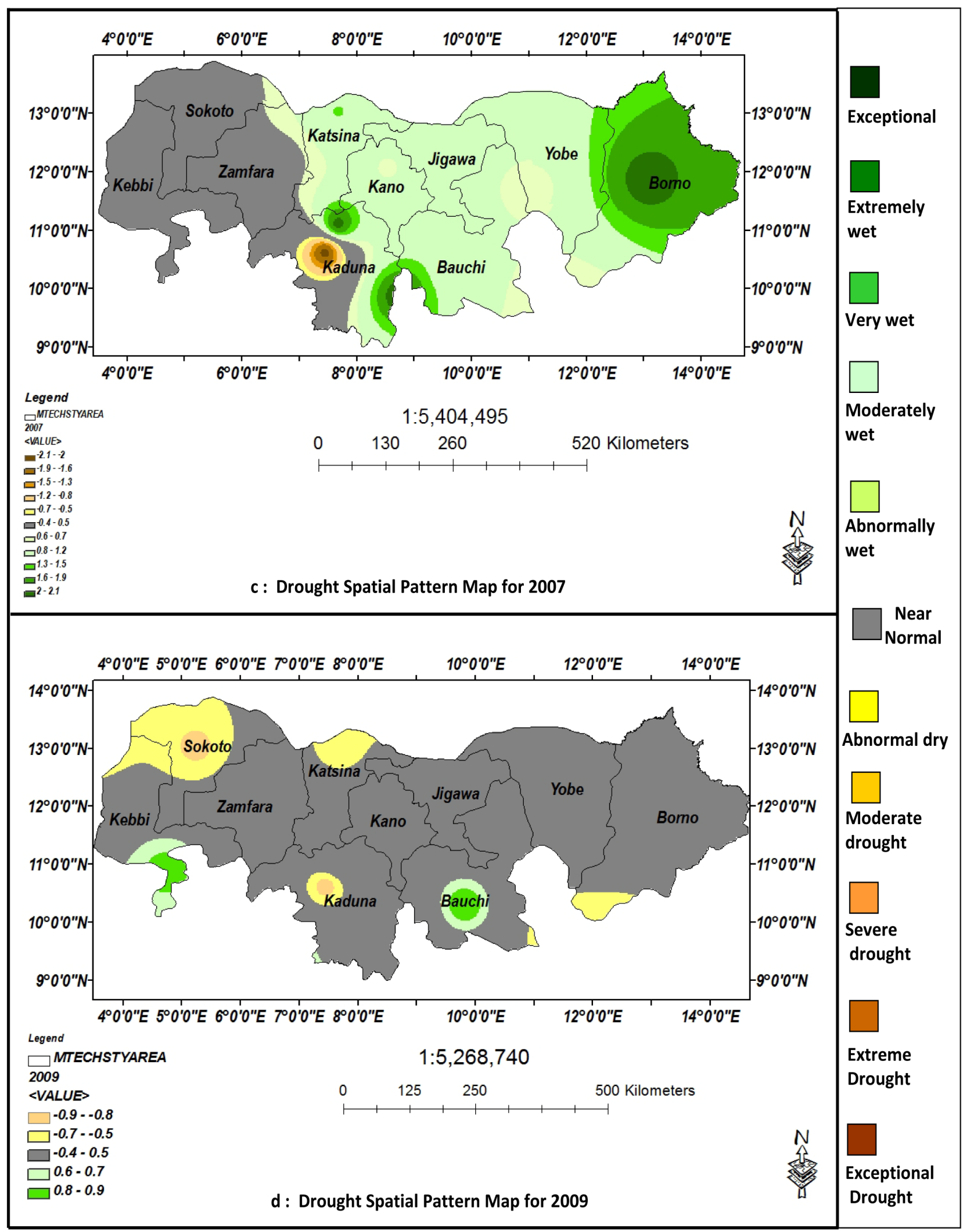

Figure 7. Drought spatial pattern map for 2004, 2005, 2007 and 2009 over the study area. 
drought classes, Exceptional drought was recorded over Sokoto and part of Kebbi while some part of Sokoto, Kastina, Jigawa Yobe and Borno state was under influence of extreme and severe drought condition. Moderate drought condition cut across some part of Sokoto, Zamfara, Kano and Jigawa state and it was also experienced over part of Yobe and Borno state. Abnormally dry condition and near normal seems to be advancing into the region (study area) as it appeared on the map over Kaduna, Zaria station and it's environ.

Figure 6(b) depicts the spatial extent and pattern of each drought classes that manifested over the study area in 1990. This map revealed that the near normal drought condition that was evidence over kaduna and zaria station in 1987 had advanced into more space with time over the study area. The whole of Borno, Yobe, Jigawa, Kano, Bauchi, Zamfara and Kebbi states were still left in drought condition but there is reduction in the drought intensity over the meteorological stations in the mentioned state.

Figure 6(c) revealed the drought case over the study area in 1993; the legend depicts that there was a drastic change on the drought occurrence over the study area. Near normal condition was found to be wide spread and cut across the whole region, major part of Zamfara, and some part of Kaduna Kastina bauchi, Borno state were found to be under influence of wet condition. Although some part of Kastina, kaduna state and part of Borno state was still under drought condition.

Figure 6(d) shows the resulted SPI spatial pattern over the study area for the year 1996, it could be noted from the map that drought condition has reduced tremendously over the study area. Only minor part of Kastina state was recorded to be under the influence of drought condition.

The drought spatial pattern maps of the modeled years considered for covered study period in the $21^{\text {st }}$ century depicts there was an obvious improvement in precipitation (rainfall) over the area of study. Figures 7(a)-(c) show that wet condition had return to most part of the study area except bauchi that was still left in drought condition but the dryness still persist over kaduna station till 2009. Figure 7(d) shows there is drastic reduction in rainfall over the study area and drought event manifest in some part of the study area including kaduna station but resulted graph plotted for SPI analysis shows that the whole region was left in wet condition.

\subsection{Vegetation Cover Index Maps}

Figure 8 shows the Normalized Differential Vegetation Index maps over each of the selected part of the study area. These maps were later classified in ArcGIS 9.3 using threshold values on Table 2 to obtain the Greenness Index Maps as shown in Figure 9.

It could be noted for Figure 8 below that there is less vegetation across the three selected part of the study area in 1986 as two-third of the whole spatial extent was revealed to be cover with bare surface. Most of the river channels also appear as bare surface which simply means there is southward drifting of the white sands from the Sahara desert by Northeast trade wind and this could also has contributed to depletion of vegetation in the study area (Sudan-Sahel).

Greenness Index Map also pointed to the fact that the built up area have almost similar reflectance's in both the Near-Infrared band and Visible or red band as they always revealed negative NDVI value.

\section{Land Cover Distribution Maps}

Land use/Land cover geo-analysis for selected part of Kano and Borno was carried out in order to show the spatial extent to which, not only the drought occurrence has impacted but the contribution of anthropogenic activities in the selected geographical region to vegetation depletion. This become highly imperative in vegetation response analysis to drought in geographical location since vegetation depletion could be as a result of drought event or daily activities of the inhabitants of that location.

Classified Landsat images for 1986, 2000 and 2005 over selected part of Kano State (Figure 10) revealed the spatial distribution and extent of each of the Landuse/Landcover categories over the three different years considered for this study. These images simply revealed the change in the vegetation cover (the green tone), water bodies (the blue tone) and other features as depicted on their respective legend.

Table 3 contained the Landuse/Landcover (LULC) result for selected part of Kano State; the result was converted into percentage (Table 4) and average to determine the rate at which of the land cover category has change over the time. All the results gotten from the classified images were shown on Table 3 and summary in Figure 11 (chart) for easy interpretation. The result shows that there exists a change in each of the LULC categories considered in this study with in the years of study. Dense vegetation which formed the original vegetation cover of the study area actually decreased from $2.15 \%$ in 1986 to $2.02 \%$ in 2000 which might be due to 


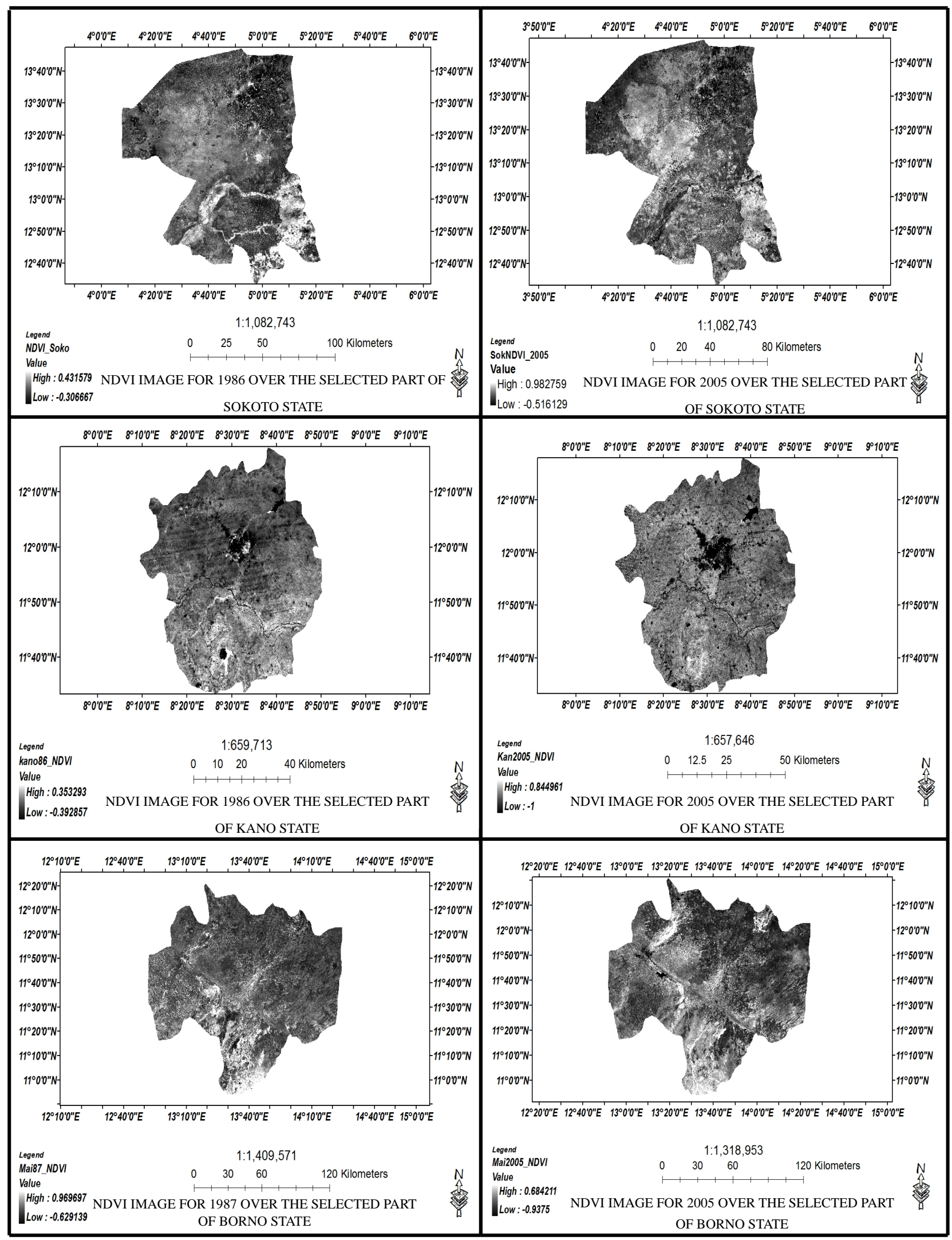

Figure 8. Normalized differential vegetation maps for some selected part of the study area. 


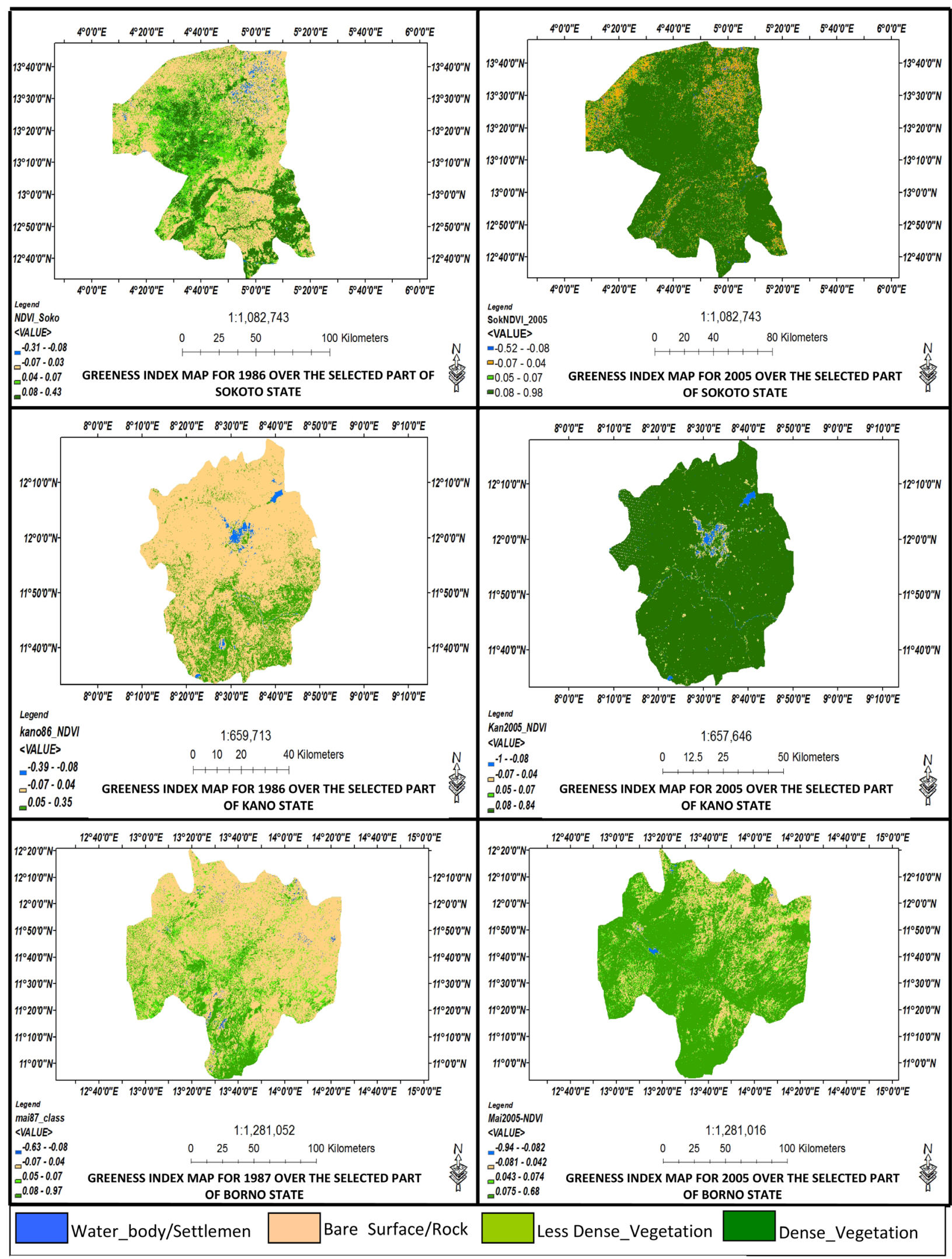

Figure 9. Greenness index maps for some selected part of the study area. 


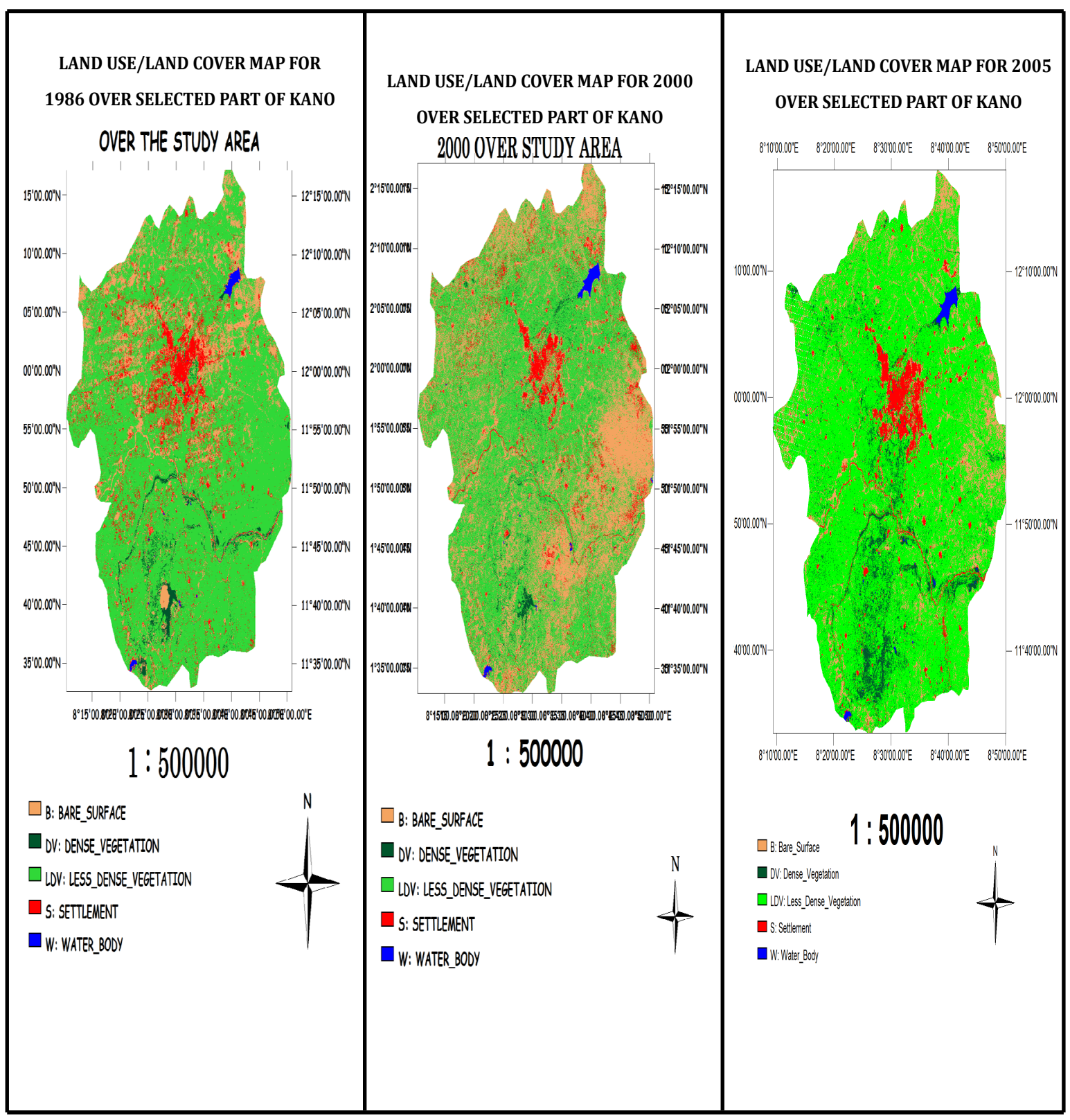

Figure 10. Land use/land cover map for 1986, 2000 \& 2005 respectively over selected part of Kano.

Table 3. Showing the spatial extent of land cover over selected part of Kano after classification.

\begin{tabular}{|c|c|c|c|c|c|c|}
\hline Land Cover Types & $\begin{array}{c}1986 \\
\text { Area in Hectares }\end{array}$ & Area in \% & $\begin{array}{c}2000 \\
\text { Area in Hectares }\end{array}$ & Area in \% & $\begin{array}{c}2005 \\
\text { Area in Hectares }\end{array}$ & Area in \% \\
\hline Dense Vegetation & 86329.9913 & 2.15 & 81328.9680 & 2.02 & 267334.200 & 6.65 \\
\hline $\begin{array}{l}\text { Less Dense } \\
\text { Vegetation }\end{array}$ & 2924759.5470 & 72.68 & 2241928.5885 & 55.70 & 2978781.300 & 42.79 \\
\hline Settlement & 336745.8540 & 8.37 & 234027.9068 & 5.82 & 203448.600 & 1.06 \\
\hline Bare Surface & 661779.0630 & 16.44 & 1447532.6558 & 35.97 & 541032.300 & 44.38 \\
\hline Water Body & 14789.4480 & 0.37 & 19535.4248 & 0.49 & 23994.900 & 5.12 \\
\hline Total & 4024403.903 & 100 & 4024353.543 & 100 & 4014591.300 & 100 \\
\hline
\end{tabular}




\section{Area in Percentage of the Land Cover Categories for 3 diff. years considered}

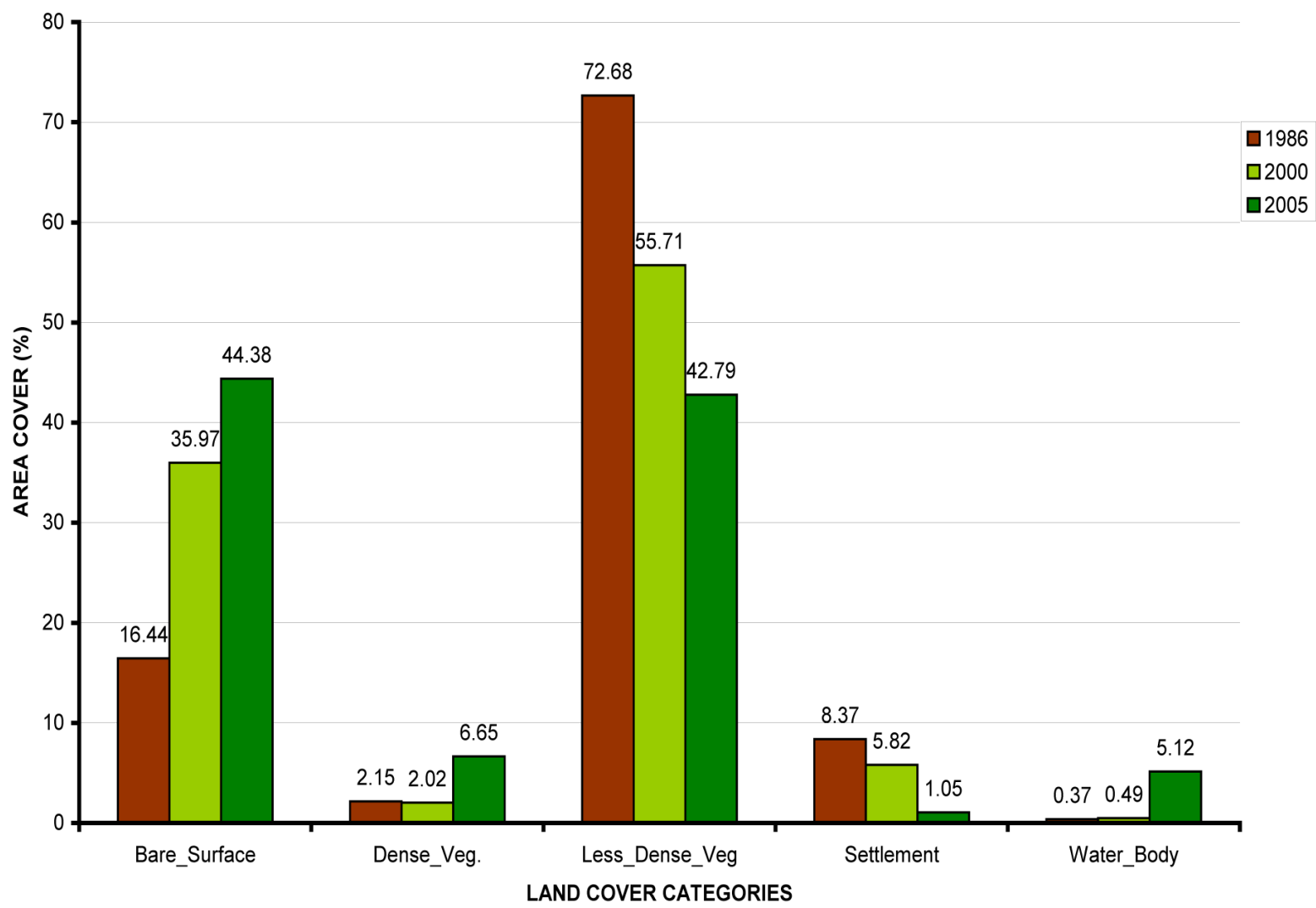

Figure 11. Percentage area of the land cover categories for 3 diff. years considered over Kano.

Table 4. Comparison of areas and rates of change of the five Landuse/Landcover classes between 1986-2000 and 1986-2005 for selected part of Kano.

\begin{tabular}{cccccccc}
\hline $\begin{array}{c}\text { Land } \\
\text { Cover Types }\end{array}$ & $\begin{array}{c}\mathbf{1 9 8 6} \\
\text { Area in } \\
\text { Hectares (ha) }\end{array}$ & $\begin{array}{c}\mathbf{2 0 0 0} \\
\text { Area in } \\
\text { Hectares (ha) }\end{array}$ & $\begin{array}{c}\text { Area in Hectares } \\
\text { (ha) }\end{array}$ & $\begin{array}{c}\text { Change between } \\
\mathbf{1 9 8 6} \text { and 2000 } \\
\text { (ha) }\end{array}$ & $\begin{array}{c}\text { Average Rate } \\
\text { of Change } \\
\text { (ha/year) }\end{array}$ & $\begin{array}{c}\text { Change between } \\
\text { 1986 and 2005 } \\
\text { (ha) }\end{array}$ & $\begin{array}{c}\text { Average Rate } \\
\text { of Change } \\
\text { (ha/year) }\end{array}$ \\
\hline $\begin{array}{c}\text { Dense } \\
\text { Vegetation }\end{array}$ & 86330 & 81329 & 1098203.4 & -5001.02 & -3572.2 & 1011873.41 & 56215.19 \\
$\begin{array}{c}\text { Less Dense } \\
\text { Vegetation }\end{array}$ & 2924760 & 2241929 & 7063590.6 & -682831.0 & -487736.0 & 4138831.05 & 229935.1 \\
Settlement & 336746 & 234028 & 173888.10 & -102718.0 & -73370.0 & -162857.75 & -9047.65 \\
Bare Surface & 661779 & 1447533 & 7325483.4 & 785753.6 & 561253.0 & 6663704.34 & 370205.8 \\
Water Body & 14789.4 & 19535.4 & 845739.00 & 4745.977 & 3389.98 & 830949.55 & 46163.86 \\
\hline
\end{tabular}

Note: A decrease carries Negative sign while an increase carries positive sign.

harsh weather condition of the area under consideration but later increased drastically in 2005 to $6.65 \%$ which simply shows there is improvement in rainfall that year. Water Body category also appreciated towards 2005 by $4.63 \%$ and by $0.12 \%$ between 1986 and 2000 . It also important to note that most of the dense vegetation is found along the river banks (riparian vegetation). Less Dense vegetation was also seen to have reduced drastically as the result revealed its percentage drop from $72.68 \%$ in 1986 to $55.71 \%$ in 2000 and later to $42.79 \%$, which shows that there must have been reduction in agricultural practices in this region due to the effects of drought. Also settlement has reduced from $8.37 \%$ in 1986 to $5.8 \%$ in 2000 which simply indicate the reduction in the populace of the area which might also due to increase in emigration and high mortality rate in the region. There is increase in water body $(0.37 \%$ in 1986 to $0.49 \%$ in 2000$)$ which shows that the drought intensity has really 
reduced towards year 2000 and beyond. The year 2000, from the results seems to be drought free year.

Figure 12 was the classified Landsat images for 1987, 2000 and 2005 over selected part of Borno State. These images simply revealed the change in the vegetation cover (the green tone), water bodies (the blue tone) and other features as depicted on their respective legend. Table 5 and Table 6 below show the magnitude of the spatial extent and change that occurred on each of the land cover types present on the Landuse/Landcover map (Figure 12) over the years considered for this analysis (1987, 2000 and 2005).

Figure 13 is the summary of whole information contained in Table 5 and Table 6 . It could be noted that the vegetation cover types actually increased towards 2005 from 1987.

Clearly, the bare surface depreciated from $71.99 \%$ in 1987 to $62.39 \%$ in the year 2000 and later to $44.38 \%$ in 2005, which simply indicates that more exposed surfaces were covered by vegetation due to improvement in rainfall.

It could also be inferred from the histogram that the settlement (or built-up area) actually appreciated from $2.53 \%$ in the year 1987 to $3.01 \%$ in 2000 and later depreciated to $1.05 \%$ in 2005 despite the improvement on the rainfall and vegetation of the region which encourages agricultural activities. It could also be noted that the spatial extent covered by water body in 2005 drastically increased from $0.32 \%$ to $5.12 \%$ in 2005, which simply agreed to the fact that there is increment in the amount of rainfall in the region and is also in accordance with the result of standardize precipitation index (SPI) analysis carried out over the region which showed the location as a drought free area for that particular year (2005). The 2005 classified image for Borno (Figure 12) shows that wet land is evident in the northern part of the image which is actually close to the chad basin.

\section{Conclusions}

Analysis is performed over the study area, Sudano-Sahel region in Nigeria which has a characteristic single peak rainfall distribution throughout the year experienced many years of drought episodes. This had in turn terribly influenced the standard of living of the people within the area as their major source of income (agriculture) is rain-fed. Also the Vegetation Cover map depicts decrease in settlement in 2000 relative to 1986 which simply means reduction in the population of people living in that region which might be due to increase in mortality rate, migration out of the region and low fertility rate.

Table 5. Showing the spatial extent of land cover over selected part of Borno State after classification.

\begin{tabular}{ccccccc}
\hline Land Cover Types & $\begin{array}{c}\mathbf{1 9 8 7} \\
\text { Area in Hectares }\end{array}$ & Area in \% & $\begin{array}{c}\mathbf{2 0 0 0} \\
\text { Area in Hectares }\end{array}$ & Area in \% & $\begin{array}{c}\mathbf{2 0 0 5} \\
\text { Area in Hectares }\end{array}$ & Area in \% \\
\hline $\begin{array}{c}\text { Dense Vegetation } \\
\text { Less Dense }\end{array}$ & 53364.0128 & 0.32 & 324440.1 & 1.97 & 1098203 & 6.65 \\
$\quad \begin{array}{l}\text { Vegetation } \\
\text { Settlement }\end{array}$ & 4065869.266 & 24.63 & 5333405 & 32.31 & 7063591 & 42.79 \\
Bare Surface & 418304.6888 & 2.53 & 497248.2 & 3.01 & 173888.1 & 1.05 \\
Water Body & 11883020.12 & 71.99 & 10298605 & 62.39 & 7325483 & 44.38 \\
$\quad$ Total & 85959.6053 & 0.52 & 53206.2 & 0.32 & 845739 & 5.12 \\
& $\mathbf{1 6 5 0 6 5 1 7 . 6 9}$ & $\mathbf{1 0 0}$ & $\mathbf{1 6 5 0 6 9 0 4 . 5}$ & $\mathbf{1 0 0}$ & $\mathbf{1 6 5 0 6 9 0 4 . 1}$ & $\mathbf{1 0 0}$ \\
\hline
\end{tabular}

Table 6. Comparison of areas and rates of change of the five land use/land cover classes between 1987-2000 and 1987-2005 for selected parts of Borno State.

\begin{tabular}{|c|c|c|c|c|c|c|c|}
\hline $\begin{array}{c}\text { Land } \\
\text { Cover Types }\end{array}$ & $\begin{array}{c}1987 \\
\text { Area in hectares } \\
\text { (ha) }\end{array}$ & $\begin{array}{c}2000 \\
\text { Area in } \\
\text { Hectares (ha) }\end{array}$ & $\begin{array}{c}2005 \\
\text { Area in } \\
\text { hectares (ha) }\end{array}$ & $\begin{array}{c}\text { Change } \\
\text { between } 1987 \\
\text { and } 2000 \text { (ha) }\end{array}$ & $\begin{array}{c}\text { Average Rate of } \\
\text { Change } \\
\text { (ha/year) }\end{array}$ & $\begin{array}{c}\text { Change } \\
\text { between } 1987 \\
\text { and } 2005 \text { (ha) }\end{array}$ & $\begin{array}{l}\text { Average Rate of } \\
\text { Change (ha/year) }\end{array}$ \\
\hline $\begin{array}{c}\text { Dense } \\
\text { Vegetation }\end{array}$ & 53364.01 & 324440.1 & 1098203 & 271076.1 & 20852.0 & 1044839 & 58046.63 \\
\hline $\begin{array}{l}\text { Less Dense } \\
\text { Vegetation }\end{array}$ & 4065869.27 & 5333405 & 7063591 & 1267536 & 97502.8 & 2997721 & 166540.07 \\
\hline Settlement & 418304.69 & 497248.2 & 173888.1 & 78943.51 & 6072.6 & -244417 & -13578.70 \\
\hline Bare Surface & 11883020.12 & 10298605 & 7325483 & -1584416 & -121878.1 & -4557537 & -253196.48 \\
\hline Water Body & 85959.61 & 53206.2 & 845739 & -32753.4 & -2519.49 & 759779.4 & 42209.97 \\
\hline
\end{tabular}

Note: A decrease carries Negative sign while an increase carries positive sign. 


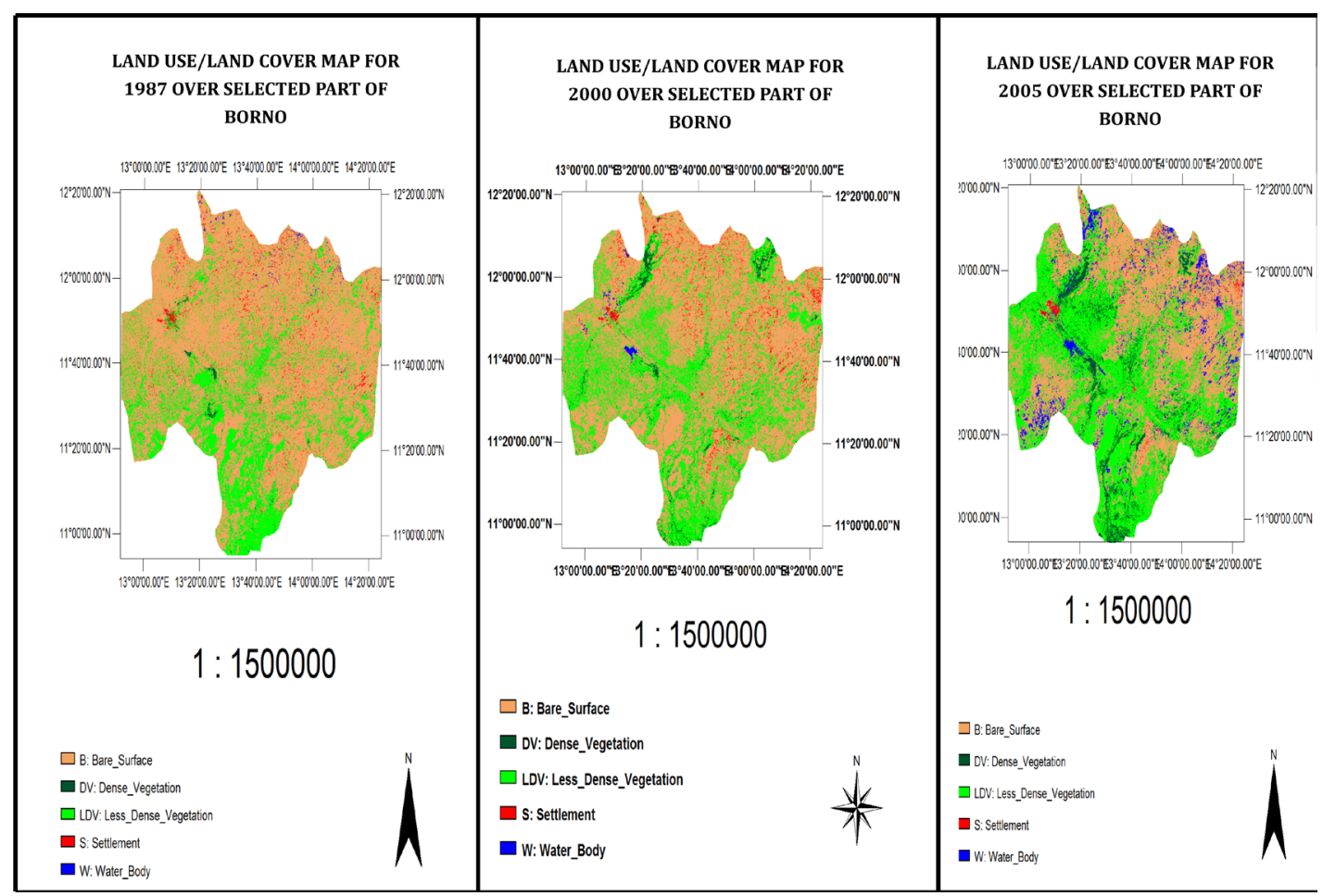

Figure 12. Land use/land cover map for 1986, 2000 \& 2005 respectively over selected part of Borno.

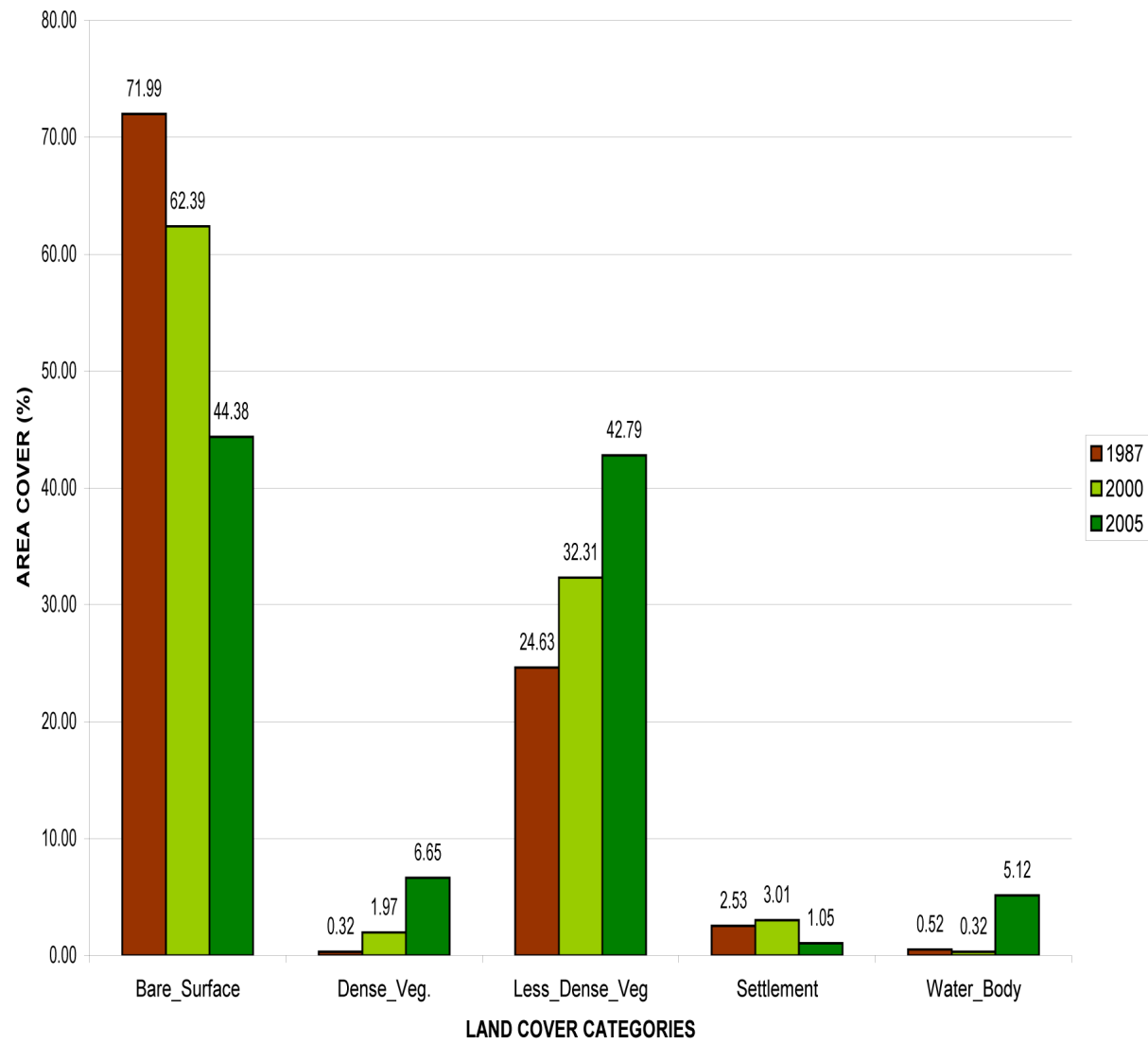

Figure 13. Percentage area of the land cover categories for the 3 different years under consideration over Borno State. 
The drought episodes of 1983 and 1987 over Maiduguri and the extreme edge of Sokoto respectively seemed to be the most serious occurrence throughout the years of this study and it was confirmed to have claimed many live stocks, even lives of the dwellers and left the regions in severe dry condition. But later in 1990s the dryness started to reverse as near normal condition was seen to be spreading over the area towards 2000 which shows the return of rainfall to the region. 2000 was wet year over most part of the Sahel as depicted on drought spatial pattern map for 2000 and it was also shown by the vegetation cover map as the water body had increased in 2000 relative to 1986.

The result gotten from Drought and Vegetation Response analysis in 1986, confirmed that whenever there is drought outbreak, vegetation respond by depreciating in growth due to insufficient or availability of plant available water in the soil. As the drought persists over a long period of time, it definitely results in vast reduction in floral population in an ecosystem which may also leads to increase in spatial extent of bare surface, decrease in fauna population as the region would no longer be conducive for living.

\section{References}

[1] Adefolalu, D.O. (1986) Rainfall Trends in Nigeria. Theoretical and Applied Climatology, 37, 205-219. http://dx.doi.org/10.1007/BF00867578

[2] Kamara, S.I. (1986) The Origin and Types of Rainfall in West Africa. Weather, 41, 48-56. http://dx.doi.org/10.1002/j.1477-8696.1986.tb03787.x

[3] Kalu, A.E. (1987) The Recurrence of Severe Droughts in Northern Nigeria. Proceedings of the 1985 Commonwealth Meteorologists Conference, Meteorological Office College, Reading.

[4] Lockwood, J.G. (1988) Climate Variability in Semi-Arid Regions at Low Latitudes. In: Parry, M.L., Carter, T.R. and Konijn, N.T., Eds., The Impact of Climate Variations on Agriculture: Vol. 2, Assessments in Semi-Arid Region, ILASA/UNEP, Kluwer, Dordrecht, 85-120.

[5] Nicholson, S.E., Tucker, C.J. and Ba, M.B. (1998) Desertification, Drought, and Surface Vegetation: An Example from the West African Sahel. Bulletin of the American Meteorological Society, 79, 815-829. http://dx.doi.org/10.1175/1520-0477(1998)079<0815:DDASVA>2.0.CO;2

[6] Nicholson, S.E. (1985) Sub-Saharan Rainfall, 1976-1984. Journal of Applied Meteorology, 24, 1388-1391. http://dx.doi.org/10.1175/1520-0450(1985)024<1388:SSR>2.0.CO;2

[7] Nicholson, S.E. and Palao, I.M. (1993) A Re-Evaluation of Rainfall Variability in the Sahel. International Journal of Climatology, 13, 371-389. http://dx.doi.org/10.1002/joc.3370130403

[8] Okorie, F.C. (2003) Studies on Drought in the Sub-Saharan Region of Nigeria Using Satellite Remote Sensing and Precipitation Data. Department of Geography, University of Lagos, Lagos, 1-68

[9] Houndenou, C. and Hernandez, K. (1998) Climate of the Sahel 1961-1990. Benin, Secheresse, 9, 23-34.

[10] Ekpoh, I.J. (1999) Rainfall and Peasant Agriculture in Northern Nigeria. Global Journal of Pure and Applied Sciences, 5, 123-128.

[11] Camberlin, P. and Diop, M. (2003) Application of Daily Rainfall Principal Component Analysis to the Assessment of the Rainy Season Characteristics in Senagal. Climate Research, 23, 159-169. http://dx.doi.org/10.3354/cr023159

[12] Nicholson, S.E. (1981) The Nature of Rainfall Fluctuation in Subtropical West Africa. Monthly Weather Review, 108, 473-487. http://dx.doi.org/10.1175/1520-0493(1980)108\%3C0473:TNORFI\%3E2.0.CO;2

[13] Kanote, M. (1984) Climate of the Sorghum and Millet Cultivation Zones of the Semi-Arid Tropical Regions of West Africa. Proceedings of the International Symposium, 15-20 November 1982, ICRISAT Centre, India.

[14] Hayward, D. and Oguntoyinbo, J. (1987) The Climatology of West Africa. Hutchinso, London, 271 p.

[15] Oladipo, E.O. (1993) Some Aspects of the Spatial Chracterisitics of Drought in Northern Nigeria. Natural Hazards, 8, 171-188. http://dx.doi.org/10.1007/BF00605440

[16] Olaniran, O.J. and Sumner, G.N. (1989) A Study of Climate Variability in Nigeria Based on the Onset, Retreated and Length of the Rainy Season. International Journal of Climatology, 9, 253-269. http://dx.doi.org/10.1002/joc.3370090304

[17] Muller, R.A and Orbeelander, T.M. (1987) Physical Geography Today: A Portrait of a Planet. Random House Inc., New York.

[18] Mckee, T.B., Doesken, N.J. and Kleist, J. (1993) The Relationship of Drought Frequency and Duration to Time Scales. 8th Conference on Applied Climatology, Anaheim, 17-22 January 1993, 179-148.

[19] Rouse, J.W., Haas, R.H., Schell, J.A. and Deering, D.W. (1974) Monitoring Vegetation Systems in the Great Plains with ERTS. 3rd ERTS-1 Symposium, Washington DC, 10-14 December 1973, 309-317. 
Scientific Research Publishing (SCIRP) is one of the largest Open Access journal publishers. It is currently publishing more than 200 open access, online, peer-reviewed journals covering a wide range of academic disciplines. SCIRP serves the worldwide academic communities and contributes to the progress and application of science with its publication.

Other selected journals from SCIRP are listed as below. Submit your manuscript to us via either submit@scirp.org or Online Submission Portal.
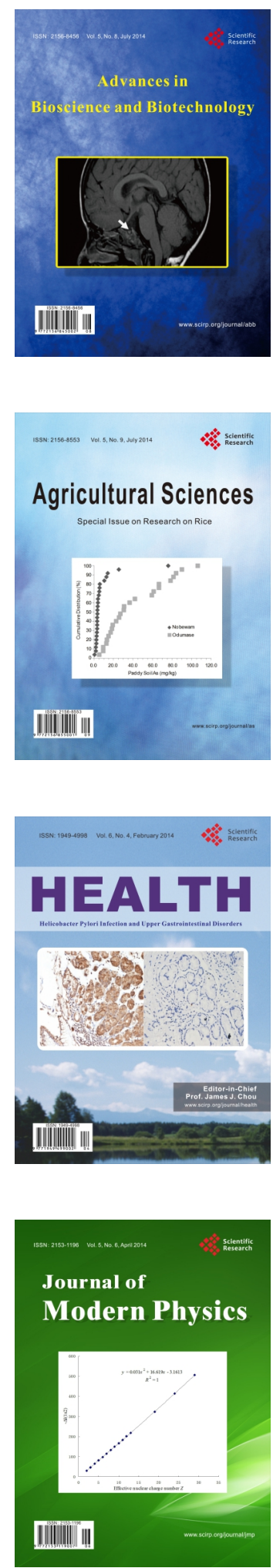
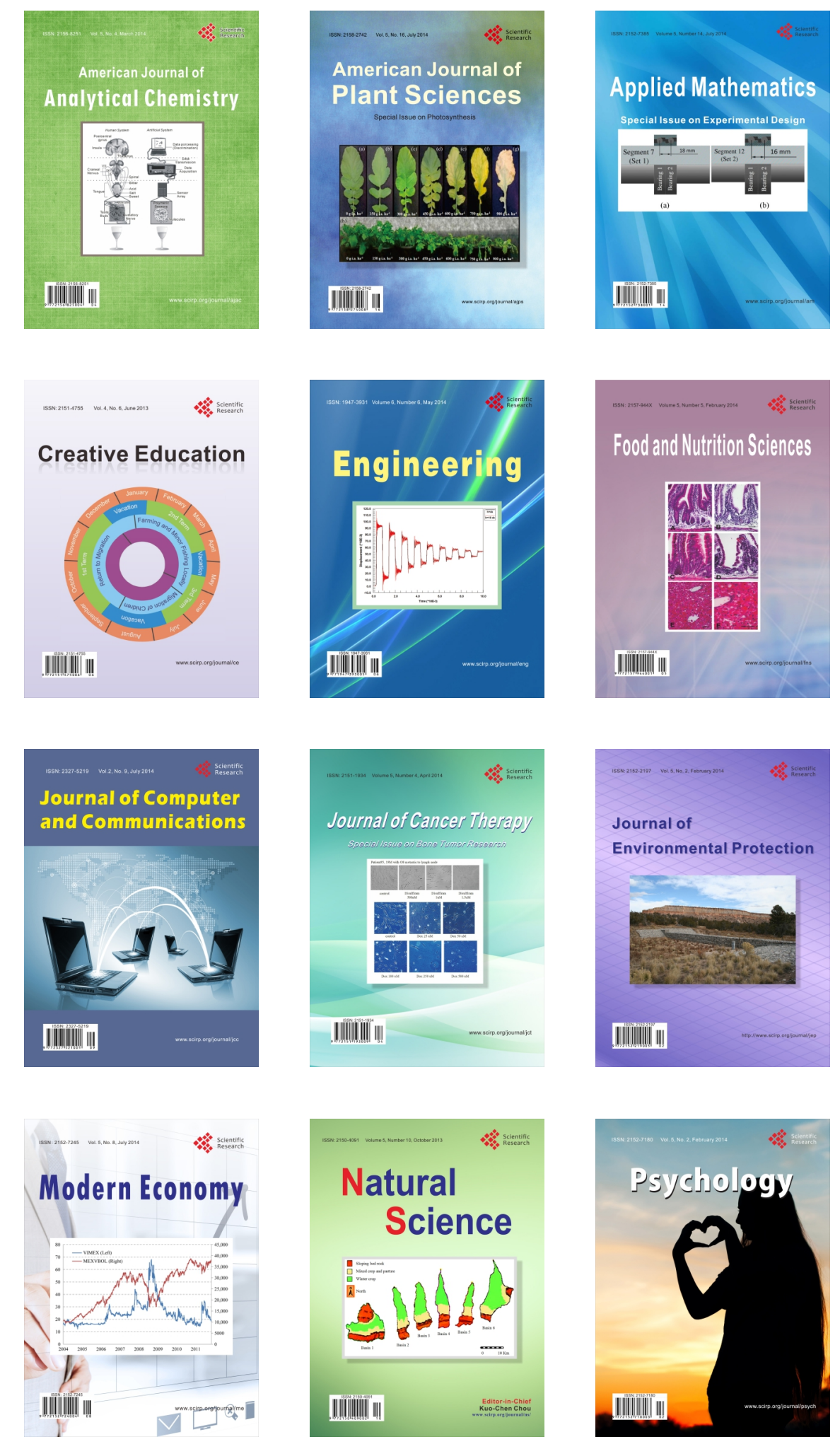